\title{
Introduction: Transforming China
}

\section{EMILE KOK-KHENG YEOH AND KATE HANNAN (GuEST EDITORS)}

Over the last three decades the highly remarkable economic performance of the once low-income and inward-looking country of China has attracted increasing interest from academics and policy-makers. However, beyond the stated intention of fostering modernisation and marketisation, China's reform and transformation have not been achieved in accordance with an agreed and clearly established blueprint. It has been a result of policies and ideas formulated and tested as marketbased reforms continued to push direct administrative management back into the past.

At the same time as domestic economic reform and attendant social transformation were progressing at impressive speed, China has emerged as a regional and global power. The transformation of China's international profile has been one of the most pivotal changes in the contemporary world. It is a change that has given rise to much debate over the weight to be given to domestic and external forces in explaining China's current world position. Nevertheless, rather than engaging in further debate on this issue we, the editors, have simply divided the five contributions to this special issue of the Copenhagen Journal of Asian Studies into two sections. The first section contains three papers that focus on China's domestic front and the second offers two papers concerned with China's participation in the international arena.

In the first paper focusing on China's domestic issues, LooSee Beh examines the complexities of governance in the country and a possible connection between the moral degeneration of public administrators and crisis in governance. Her article also traces the Chinese government's policies towards religions and religious communities. She notes the remarkable surge in religious adherence in recent years and the evolving Communist Party stance towards the practice of religion. This stance has moved from the persecution of the earlier years to today's freedom of worship as long as the latter is not considered to pose a challenge to the Party's monopoly on political power. In view of the existence of a 'silent crisis in governance' in the People's Republic, Beh argues that the re-instilling of spirituality into work practices would benefit from a reinvention of public administration. She notes the extent of 'unethical decision-mak- 
ing' in China today while recognizing that 'most Chinese are struggling with what spirituality means for their work and family'.

Besides the crisis in governance observed by Beh, recent decades of reform that have brought about stunning economic miracles have also aggravated the problems of unemployment, poverty and inequality that continue to plague China in her politico-socioeconomic development into the new millennium, and with poverty being concentrated in the western region and in the ethnic minority areas, ethnoregionalization of poverty inevitably ensues, presenting the country not only with economic challenges, but also long-term sociopolitical uncertainties. Addressing such issues, the article by Emile Kok-Kheng Yeoh analyses the problem of poverty in China as a multi-facetted phenomenon, sees poverty alleviation as inevitably linked to the country's regional and minority policies, and hence argues for a stronger emphasis on the elements of decentralisation and localisation. On the other hand, although the central government of China has consistently sought to exercise strong control over the country since 1949, it has at times done so through decentralist rather than centralist policies. For instance, Dengist economic reform policies have had a strongly decentralist element, with continuing devolution of control to provincial governments. Politically unitary yet remarkably decentralised in fiscal terms, China has thus its share of worries about regional centrifugal tendencies, not least evident in the recent civil disturbances in Tibet. China is living through an age that witnesses the revival of old regionalisms, as well as the creation of new regionalisms brought about by increased local autonomy, rapid economic growth and increasingly globalising trade and business linkages. While the oft-cited 'China deconstructs' scenario seems at present far-fetched, the challenges posed by central-peripheral conflicts, ethnic resource contest and ethnoterritorial aspirations are real, in particular as they are being exacerbated by the country's 'retreat from equality' and growing interregional economic disparity. In the light of these daunting exigencies, Yeoh's article explores the political economy of regional development in China, focusing on the intricate link between the country's ethnic diversity, poverty and the role of the State in the economy.

China's 'retreat from equality' and increased regional disparity is again clearly on display when Kate Hannan considers the problems encountered by China's rural-to-urban migrant workers. While the funds these migrant workers remitted 'home' to the countryside have boosted rural household income, they have accentuated the difference between 
families with migrant worker funding and those without. At the same time, the difference between the working conditions, wages and prospects of permanent urban residents and those of migrant workers and rural residents has been underlined.

Hannan notes that when members of rural households made the decision to send their most productive family members to work in coal mines or to urban areas to find work in the construction sector or in labour-intensive/low-profit manufacture for export, they have found that their migrating family members have been obliged to work very long hours, often without commensurate wages. They have also been obliged to accept wage payments that have often been delayed for considerable periods and to work in what were often dirty and dangerous conditions. They have often been subject to strict factory discipline and have received low wages in return for their work compared to the wages paid to permanent urban residents. China's migrant workers then found that their demands for increased wages and improved working conditions have been depreciated and ignored while they continue to be denied access to social services including adequate health care. Many young women migrants have been consigned to crowded hostel accommodation, while other migrants have had to scavenge at the bottom of the market for sub-standard and overcrowded housing. Now a significant number of China's rural-to-urban migrant workers, particularly those who are young second-generation workers, are expressing their dissatisfaction with this situation. They are not only using petitions, arbitration procedures and demonstrations to express their concern, but are also deciding not to come to the cities to work. They declare that they will not follow in their parent's footsteps in accepting unskilled, dirty and dangerous work. They are unwilling to continue to accept the low wages and the social indignities that have been visited on migrant workers. They want 'decent work'. They also want improved living conditions and to access higher wages and an attendant increased level of consumption.

In the first of the two internationally focused papers offered in this special issue of the journal, Gerald Chan looks at contemporary China in the context of global governance. Chan discusses China's economic ascendance over the last three decades and the country's concomitant expansion of her 'soft power'. He examines the way China's emergence impacts on global governance and the exact nature of the Asian giant's aspirations and demands, as well as the country's limitations in this regard. Highlighting China's heightened participation in international 
organisations, and the signing and ratification of major international treaties, Chan surveys the major principles underlying China's involvement in global governance as well as how other protagonists in an arena that comprises a wide range of players view China. Chan concludes his article by noting that Sino-American interaction in global governance is likely to play a large part in determining the coming world order.

While he has not explicitly used the concepts of 'balancing' and 'bandwagoning', Chan's approach draws attention to these two means of understanding the actions of nation-states in our globalised world. In international relations, the primary alignment response of states has been presented as a bid to balance against a potential or actual constellation of power due to the fear of being dominated or destroyed by the dominating or rising power (see Harknett and VanDenBerg 1997: 155, and Zweig and Chen 2007: 44). However, instead of balancing against the stronger power, states may bandwagon with the stronger power to gain from the benefits the latter makes possible. In other words, while 'balancing is driven by the desire to avoid losses: bandwagoning [is driven] by the opportunity for gain'. Some have also noted that bandwagoning is likely to be 'less demanding and more rewarding than balancing, requiring less effort and extracting lower costs'. Other scholars stress that states seek much more than the security that balancing presents as a primary concern - they 'seek self-extension: to obtain added values that they covet' and bandwagoning is well suited to this endeavour. (Ray and Kaarbo 2005: 215-217, and Zweig and Chen 2007: 44)

The international configuration of power is further explored by Zhao Hong in his article on China's global resource quest with particular focus on the country's interest in oil from Africa. While China's present foreign policy seems to emphasise cooperation and stability in order to promote her own security, development and wealth, her global search for energy has often been viewed by the United States and other Western powers as provocative in accelerating the global arms race and the propping up of dictatorial regimes from Burma in Southeast Asia to Sudan in Africa (Navarro 2006).

Zhao presents China's oil diplomacy as part of the country's 'going out' strategy. He does this in the context of China's oil imports from Africa increasing at a rate slightly higher than that of the rest of the world, with fifty per cent of its equity oil coming from Sudan. China is the destination for sixty-five per cent of Sudan's oil exports. Zhao also observes China's difficulty in continuing to follow a policy of non-interference in domestic affairs, particularly in relation to Sudan. In this 
respect China has come under international pressure to alter or at least soften its policy of non-interference in domestic issues.

China's presence in Africa is of course not limited to Sudan. With almost thirty of its major oil and natural gas projects in more than a dozen African countries, Zhao foresees the possibility of China coming into confrontation with the United States over oil on that continent. Foreign policy analysts in Washington warn of Beijing's strategy of 'locking up' the world's remaining oil supplies. Zhao dismisses this view as being unfounded. While pressure is mounting on China's oil diplomacy in Africa amidst accusation of being engaged in 'new colonialism' and 'propping up rogue states', Zhao holds the position that China's oil investment in Africa is not a threat but something to be encouraged. He argues that the United States could play a positive role by turning China's unilateral energy policy into a multilateral policy. After all, China is not only reaching out to Africa in its energy quest, but also to other raw material suppliers including the United States, Canada, Peru, Russia, Kazakhstan, Venezuela, Indonesia and Australia.

Zhao's article highlights the fact that China's escalating demand for energy resources is today no longer solely a matter of domestic concern, but is increasingly acquiring new dimensions that have a powerful influence on international politico-economic relations. His observations demonstrate that while both balancing and bandwagoning strategies can be expected to enhance mutual interdependence and security, China has been fostering a foreign policy position primarily tailored for resource access, development, wealth and economic gain: policy that sits more comfortably with bandwagoning than with balancing.

The articles in this special issue show that despite the highly remarkable economic achievement in recent decades, China's rise has brought domestic issues to the fore that the country's government must address. At the same time, China's global profile has spawned a host of questions that have been brought to world attention. On the domestic front there are administrative problems, expanding interregional and urban-rural disparities and labour woes and in the international arena there are questions relating to China's increased interaction with the rest of the world. There are questions over its role in global governance and there are issues relating to its international 'footprint', particularly with regard to the country's relentless quest for resources to drive its impressive and fast-paced economic growth and social transformation.

Earlier versions of the papers in this special issue were presented at the China in the World, the World in China international conference 
'Implications of a Transforming China: Domestic, Regional and Global Impacts' at the Institute of China Studies, University of Malaya, Kuala Lumpur, in August 2007.

Dr Emile Kok-Kheng Yeoh is Director and Associate Professor, Institute of China Studies, University of Malaya, Malaysia (emileyeo@gmail.com); Dr Kate Hannan is Associate Professor, School of History and Politics, Faculty of Arts, University of Wollongong, Australia (kateh@uow.edu.au).

\section{REFERENCES}

Gries, P. H. and S. Rosen (eds) 2004. State and Society in 21st-century China: Crisis, Contention and Legitimation. New York and London: Routledge/Curzon.

Harknett, R. and J. VanDenBerg 1997. 'Alignment Theory and Interrelated Threats: Jordan and the Persian Gulf Crisis'. Security Studies 6 (3): 113-154.

Navarro, P. 2006. The Coming China Wars: Where They Will Be Fought, How They Can Be Won. New Jersey: FT Press.

Ray, J. L. and J. Kaarbo 2005. Global Politics. 8th edition. New York: Houghton Mifflin Company.

Zweig, D. and Z. Chen 2007. China's Reforms and International Political Economy. London and New York: Routledge. 